\title{
Funding Library Research
}

\begin{abstract}
Academic librarians who want to do research and need to find grants to support it should consider how funding agents approach decisions on what proposals to finance. Funding agents look for good ideas in their areas of interest. They consider whether the idea is well researched and backed up with a pragmatic plan of action. Other factors include the qualifications of the proposer and the soundness of the budget.
\end{abstract}

T

HE TOPIC I HAVE BEEN asked to address poses a single question: What makes good library research from a funding point of view? I would like to answer this question with a single sentence.

Now at first hearing, you may think that this sentence provides a simplistic answer, an obvious, common sense response, to which you might feel compelled to reply: "Well, of course. But how do you do it?" In the balance of my remarks, I shall try to explain just that .... what is hidden behind the words in this single sentence.

So, what makes good library research from a funding point of view? My response is: A good idea, well researched, with a pragmatic plan of action and reasonable budget, an idea that falls within the funder's area of interest and is to be carried out by a well-qualified person. Now let's dissect that phrase.

\section{A GOOD IDEA}

Behind that simple phrase lurks two questions. What is a good idea? And how can I, an academic librarian, come up with one? Do you wake up one morning and bingo, there it is? Perhaps that happens to some people, but for most of us, our ideas

Nancy E. Gwinn is program officer, Council on Library Resources, Inc., Washington, D.C. This article is based on an address given at a conference in March 1979 at the University of North Carolina at Chapel Hill. derive from the work we are doing and our own experiences. What kinds of information do you need in order to perform your work better?

An example of this is a proposal that came into the Council on Library Resources some time ago from a librarian whose primary responsibility lay in the area of personnel, including such things as recruitment, staff development and training, longrange planning, etc. This person proposed to investigate current approaches and methodologies in the area of training and job analysis, both in selected academic libraries and in private companies. She had tried to implement a job analysis program at her library with some success. But she learned that not many librarians have had experience in this area and that there is a great deal of knowledge on the subject that perhaps has not been suitably adapted for use by libraries.

Bingo, a budding research topic growing out of her own experiences that presumably will, if disseminated properly, be of service to libraries as a whole.

So now that I have an idea, how can I be sure that it's a good one? I think that first I would pose a number of questions to test it:

1. Is the planned result of what I want to do something that my library, or libraries at large, really need? Do other people think we need it? Will it fill a gap or advance the state of knowledge of the profession?

2. Has someone else already done it; 
and, if so, is what I plan to do merely duplicative? Or will it improve on what has been done, show it to have been wrong, or merely corroborate what everyone already knows?

Starting with a good idea seems simple, but it is amazing how some people start from other points of view. For example, I received a call from an academic librarian, who said, "I have a sabbatical coming up in 1980 , and I'm thinking of some ideas for research that I would like to discuss with you."

"Fine, what are they?"

"Well, I thought I might go to Florence and look at the Italian art libraries there. They have a lot to tell us.

When questioned closely, it appeared that the person had been to Florence and had seen some of the libraries and thought they were interesting, which of course they are. But it wasn't clear just what he thought they had to tell us. I replied that money for travel was carefully scrutinized, at which point he broke in and said, "Well, how about the Vatican Library? We have a lot to learn there...."

To cut a long story short, clearly the caller had an idea: he wanted to go to Italy. In fact, funders often get proposals for research that are rather thinly disguised attempts to finance travel, and seldom do they get funded. It seems to me that this particular person started from the wrong point, the travel plan instead of the good idea.

\section{Well Researched}

To answer the questions I posed earlier brings us to the second part of the phrase: A good idea, well researched. To find out if you have a good idea you'll need to do some preliminary investigation, reading in the literature, talking to your colleagues and mentors, finding out what has been done and how. Funders aren't going to be terrifically impressed with a plan that, in more elegant language of course, says, "Here is what I think is a good idea, but the first step is to find out if anyone else has done it."

Much more to the point will be a statement, supported by factual evidence, that you know the idea is worth pursuing and that you are familiar with the basic bibliography associated with it; that is, that you are in touch or in tune with that aspect of professional knowledge. This will help both you and your plan gain importance in the eyes of funding agents.

\section{With a Pragmatic Plan of action}

Now we have a good idea, well researched, and here comes the rub. How are you going to carry it out? Many a good idea has failed at this point, because the proposer couldn't develop a reasonable, pragmatic plan.

It may be impossible to put together a schedule of activities in such detail that you know exactly how you will spend every waking moment during the period of the grant. But you must be able to convince the funding agent that you have some idea of what you are getting into and how long it will take to accomplish it, even whether it's possible to accomplish it.

The plan may be flexible and undoubtedly will require some alteration during the project. To a certain extent you may have to follow guidelines set down by the agency. The U.S. Office of Education, for example, must limit its support to projects that will be concluded within a year. But if you say that you are going to publish, within a month, a multivolume set of information that hasn't been written yet, or, conversely, that you will spend seven months putting together a two-page flyer (extreme cases, to be sure).your good idea may lose out.

A relative of mine provided an example here, and I hope he will forgive me for telling this story. $\mathrm{He}$ is the registrar at a midwestern university. One day he told me that he had a great idea for automating some sort of process within his office. $\mathrm{He}$ went to a funding agent. Later he told me, "You know, Nancy, I guess I thought that if they knew I was a good person and had this great idea, they'd just give me the money and then I would decide what to do with it. But they made me realize that I needed to do a lot more planning before I even knew how much I wanted."

Funders look for a pragmatic plan that has a good chance of producing the desired result. 


\section{REASONABLE BUDGET}

All right, now we have a good idea, well researched, with a pragmatic plan of action. How much is it going to cost? Underestimating a budget can be just as big a problem as overestimating. And funders are quick to find unnecessary padding. I'm sure many proposal writers feel that funding agents are overly concerned on this point. But dollars are limited, and having the responsibility of stewardship means that funders are going to try and achieve the most gain from those few dollars.

At the same time, I think most funders are reasonable about allowable expenses. We recently suggested to a proposal writer that he revise his budget upwards since he probably couldn't live in the places suggested on the amount of money he was seeking-unless he was planning on sleeping on the floors of a lot of library reading rooms.

The budget is almost always negotiable in the beginning, and sometimes can be rearranged (although seldom increased) during the project. "Reasonable" is the key word.

\section{WITHIN THE FUNDER'S AREA OF INTEREST}

So we have a well-researched idea, a pragmatic plan, and a reasonable budget. Now we come to the real key: Does your idea fall within the funder's area of interest? This is a key element. Without it you won't even get a hearing. It is up to the funder to articulate what those areas of interest are, but it is up to you to read that information and avoid wasting both your time and the funder's by submitting inappropriate ideas, no matter how worthy.

If you are unsure about whether your idea would interest a funding agent, you can easily check either by sending a preliminary letter of inquiry with enough of the plan fleshed out to enable the funder to make a decision or by talking to program and information officers in person before you ever get to the writing stage. I hasten to add that this applies to both government and private funding agents, for it is to everyone's advantage to cut down on the paperwork.

\section{A Well-Qualified Person}

Our dissection is almost complete. We come now to the last phrase, a wellqualified person. How do you show that you are one? This relates in part to where the idea came from in the first place. If it involves your job or what you are doing, clearly you will have relevant experience and can demonstrate that you know whereof you speak.

Funders look at who will be carrying out the research and who will be responsible for the outcome. They will check to see if that person's credentials make sense in light of the project. Your record as an employee can also bear witness to your capability, conscientiousness, and follow-through. Most funding agencies reserve the right to have outside consultants and knowledgeable persons assist in proposal evaluation.

If you are unknown, quite likely the funder will check with someone who does know you and can attest to your qualifications. But in the end it will be up to you to justify a funder's choosing you for the job; so committee work, special projects, publications, and relevant professional activities of all kinds can be brought to bear.

I hope that by now I have answered the question put to me: What makes good library research from a funding point of view? A good idea, well researched, with a pragmatic plan of action and reasonable budget, an idea that falls within the funder's areas of interest, and is to be carried out by a well-qualified person. It is a simple phrase, but it can form the basis for successful research proposals on any library topic. 